Original research article

\title{
Staffing characteristics and their associations with the severe maternal outcomes at Indonesian tertiary hospitals
}

\author{
Makhfudli Makhfudli ${ }^{1}$, Ferry Efendi ${ }^{1,2}{ }^{*}$, Anna Kurniati ${ }^{3}$, Retnayu Pradanie ${ }^{1}$, \\ Susy Katikana Sebayang ${ }^{4}$ \\ ${ }^{1}$ Universitas Airlangga, Faculty of Nursing, Research Group for Community Health, Family and Gerontic Nursing, Surabaya, Indonesia \\ ${ }^{2}$ La Trobe University, School of Nursing and Midwifery, Melbourne, Australia \\ ${ }^{3}$ Ministry of Health, BPPSDMK, Center for Planning and Management of Human Resources for Health, Indonesia \\ ${ }^{4}$ Universitas Airlangga, Faculty of Public Health, Department of Biostatistics and Population Studies, Research Group for Health and Wellbeing \\ of Women and Children, Banyuwangi Campus, Indonesia
}

\begin{abstract}
Aim: Staffing is believed to have a profound influence on the reduction of maternal mortality and severe maternal morbidity. Our research aims to examine the relationship between staffing characteristics and severe maternal outcomes.

Methods: We conducted a retrospective cross-sectional study analyzing the data of deliveries and staffing from the eleven maternity units at the tertiary hospitals in the Java region of Indonesia.

Results: The present study revealed that staffing characteristics were significantly associated with severe maternal outcomes. Maternity units with a higher nurse to birth ratio reduced the odds of severe maternal outcomes by $52 \%$ (OR $=0.476$; 95\% CI: $0.307-0.739$ ). However, admission to units with a higher midwife to birth ratio increased the odds of experiencing severe maternal outcomes by 1.8 times (OR $=1.809 ; 95 \% \mathrm{CI}: 1.070-3.059)$. The likelihood of severe maternal outcomes in maternity units is reduced by $52 \%$ for every additional year of nursing experience (OR $=0.476 ; 95 \% \mathrm{CI}$ : $0.304-0.745)$, and by $69 \%$ for every additional year of midwifery experience $(\mathrm{OR}=0.313$; 95\% CI: 0.200-0.491).

Conclusions: The findings signify the prominent role of healthcare workers in maternal healthcare at the tertiary level. A further study is recommended to provide more support for the evidence-based policy in relation to developing safe staffing standards within the maternal healthcare framework.
\end{abstract}

Keywords: Indonesia; Maternal mortality; Maternal near-miss; Staffing; Tertiary level

\section{Introduction}

Approximately 830 women around the globe die from maternal complications every single day (WHO, 2018). More than $90 \%$ of maternal deaths occur in developing countries. Among South East Asian countries, Indonesia is listed as having the fourth highest maternal mortality - below Cambodia, Myanmar and Lao PDR (ASEANstats, 2015). Based on the 2015 Indonesia Inter-censal Population Survey, the maternal mortality ratio decreased slightly from 390 deaths to 305 deaths per 100,000 live births from 1991 through to 2015 (MoH, 2016).

Similar to maternal mortality, morbidity contributes to the massive burden on maternal health. Among 20 to 30 women with severe maternal morbidity, approximately one person will die (Firoz et al., 2013). Developing countries suffer a heavier burden of severe maternal morbidity than developed countries. Despite the various identification criteria that have been applied, the highest prevalence of maternal near-misses was in the Africa region (14.98\%), followed by Asia (5.07\%), and then Latin America and the Caribbean (4.93\%). A much lower prevalence was reported in North America (1.38\%) and Europe (0.79\%) (Tunçalp et al., 2012). Severe maternal outcomes refers to maternal deaths and maternal near misses that have been used as an indicator to measure the quality of maternal healthcare (World Health Organization, 2011).

Staffing is an essential element in improving the quality of maternal healthcare. It refers to the number of staff required to deliver maternity services (Sandall et al., 2011). Staffing is generally characterised by the workforce supply as measured in the ratio of staff to patients, and the turnover rate, education, experience, and job satisfaction (Dunton et al., 2007). However, only a few studies have explored the relationship between staffing and severe maternal outcomes in the health facility setting. Inconclusive results have been presented in previous studies investigating the effect of staffing on maternal health outcomes. A lower midwifery staffing was significantly associated with patient readmission within 28 days (Gerova et al., 2010). However, another study reported that no significant association was found between midwife staffing level and the

\footnotetext{
* Author for correspondence: Ferry Efendi, Universitas Airlangga, Faculty of Nursing, Research Group for Community Health, Family and Gerontic Nursing, Surabaya, Indonesia; e-mail: ferry-e@fkp.unair.ac.id http://doi.org/10.32725/kont.2020.007 
caesarean rate (Joyce et al., 2004). Significant findings related to staffing characteristics were reported in previous nursing studies. Increasing the nursing experience by one year significantly reduced the hospital-acquired pressure ulcer rates by $1.9 \%$ (Dunton et al., 2007). Every additional $10 \%$ of nurses with a bachelor degree lowered the probability of hospital mortality by $7 \%$ (Aiken et al., 2014).

The significant evidence of staffing on health outcomes is still lacking in Indonesia, despite the chronic workforce shortage in various public health facilities having been widely recognised (Kurniati et al., 2015). Only half of Indonesian women selected a health facility as the place of delivery (Kurniati et al., 2018). Ironically, approximately $41.9 \%$ of maternal deaths occur in public hospitals and $16.1 \%$ in private hospitals, while $29 \%$ of maternal deaths occur at home (Balitbangkes-MoH \& UNFPA, 2012). Maternal healthcare service in Indonesia is provided through a referral system. Antenatal care check-ups and normal delivery are recommended to be provided at the primary level of care. Women with obstetric complications or with other health problems should be referred from the primary to secondary or tertiary health facilities (MoH, WHO, POGI, \& IBI, 2013). In an emergency situation, obstetric patients can be admitted directly to secondary or tertiary facilities. Further work is suggested to establish the association between staffing levels and maternal outcomes (Makhfudli et al., 2019).

Considering the high prevalence of maternal near-miss and the high proportion of maternal deaths that occur in hospitals, this study aimed to investigate the relationship between the characteristics of the maternity workforce (nursing and midwifery staffs) and severe maternal outcomes at selected hospitals of the tertiary level.

\section{Material and methods}

A retrospective cross-sectional research design was employed to examine the relationship between maternity staffing characteristics and severe maternal outcomes. The study was carried out in eleven maternity units at six tertiary hospitals within the Java region from September to December 2017. The study location was purposively selected, based on the response received from the hospitals within the study period. All hospitals that participated in this study had a similar organizational structure, managerial system, and were nationally accredited. The data was obtained from the hospital database systems. Two data sources were used, including electronic medical record data and the personnel database. The personnel database is integrated with the payroll system within the hospital information system. All data obtained for this study were generated from the period of January to December 2016.

The Donabedian framework of structure-process-outcome was adopted as a guide to conceptualise the study (Donabedian, 2002). The structural component was the staffing characteristics, while the process component included the provision of care involving the variables of the mode of delivery, the admission procedure and the length of the patient's stay. Maternal deaths and near-miss cases served as the cumulative dependent variable of severe maternal outcomes as defined by WHO (World Health Organization, 2011).

The variables of age, place of residence and the type of complication from the women's characteristics were analysed as control variables. Additionally, the variables of the process were not treated as intermediate, but as the control variables. From the personnel database, the staffing characteristic varia- bles included nursing and midwifery, as these are the only two staffing categories at the maternity unit level available for the data analysis.

The data on maternal deaths and near-miss events was obtained from the medical records. Only single live births of mothers aged between 15 and 49 years old who delivered at the study hospital were included. Records with missing data were excluded from the data analysis. Maternal mortality is indicated by the discharge status. It refers to women who died after delivery in the study hospitals. The near-miss cases were determined using organ dysfunction and the management-based criteria by applying the codes of the ICD-10 and ICD-9 CM specified in the patient's medical record.

Multivariate logistic regression analysis was conducted to explain the associations between the variables of the staffing characteristics and severe maternal outcomes by controlling the variables of the women and the factors related to the provision of care. The data analysis was performed using SPSS version 24.

Prior to the data collection, this study received ethical approval from the Institutional Review Board (IRB) committee of the "Universitas Airlangga" number 512-KEPK, dated 31st September 2017.

\section{Results}

The data of 8,567 deliveries was obtained from eleven maternity units at six selected hospitals. After applying the inclusion and exclusion criteria, the data of 8,266 single live births by women aged $15-49$ years old were included in the analysis. Table 1 displays the summary of women's characteristics and care provision that represent controlled variables, and the outcome status as the dependent variable of severe maternal outcomes.

The characteristics of the maternity staffs included in this study are displayed in Table 2. More than half of the maternity staff $(51.7 \%)$ were midwives.

\begin{tabular}{|c|c|c|}
\hline Variables & Number (\%) & Mean \pm SD \\
\hline $\begin{array}{l}\text { Women's characteristics } \\
\text { Age, years } \\
\text { Place of residence } \\
\text { Outside city } \\
\text { Inside City } \\
\text { Type of complications } \\
\text { No complication or having other } \\
\text { contributory conditions } \\
\text { Obstetric and other maternal } \\
\text { complications }\end{array}$ & $\begin{array}{l}4,485(54.3) \\
3,781(45.7)\end{array}$ & $29.75 \pm 6.526$ \\
\hline $\begin{array}{l}\text { Provision of care } \\
\text { Admission procedure } \\
\text { No referral } \\
\text { Medical referral } \\
\text { Delivery method } \\
\text { Vaginal birth } \\
\text { Caesarean delivery } \\
\text { Length of stay (LOS), days }\end{array}$ & $\begin{array}{c}3,521(42.6) \\
4,745(57.4) \\
-\end{array}$ & $4.16 \pm 2.945$ \\
\hline $\begin{array}{l}\text { Severe Maternal outcome/SMO } \\
\text { (deaths and near-misses) } \\
\text { No SMO } \\
\text { SMO }\end{array}$ & $\begin{array}{c}8,049(97.4) \\
217(2.6)\end{array}$ & \\
\hline
\end{tabular}


Table 2. Number of in-hospital births and maternity staffs by qualification per maternity unit

\begin{tabular}{|c|c|c|c|c|c|}
\hline \multirow{2}{*}{ Unit } & \multirow{2}{*}{ All births } & \multicolumn{2}{|c|}{ Nursing $(n=201)$} & \multicolumn{2}{|c|}{ Midwifery $(n=215)$} \\
\hline & & PN (\%) & AN (\%) & PM (\%) & $\mathrm{AM}(\%)$ \\
\hline 1 & 1,143 & $1(14.3)$ & $6(85.7)$ & $3(5.4)$ & $53(94.6)$ \\
\hline 2 & 202 & $1(50.0)$ & $1(50.0)$ & $1(20.0)$ & $4(80.0)$ \\
\hline 3 & 818 & $22(57.9)$ & $16(42.1)$ & $3(17.6)$ & $14(82.4)$ \\
\hline 4 & 1,007 & $6(15.0)$ & $34(85.0)$ & $5(22.7)$ & $17(77.3)$ \\
\hline 5 & 918 & $10(29.4)$ & $24(70.6)$ & $3(12.5)$ & $21(87.5)$ \\
\hline 6 & 1,045 & $5(13.5)$ & $32(86.5)$ & $2(6.9)$ & 27 (93.1) \\
\hline 7 & 1,802 & $4(44.4)$ & $5(55.6)$ & $6(14.6)$ & $35(85.4)$ \\
\hline 8 & 159 & $1(20.0)$ & $4(80.0)$ & $0(0.0)$ & $1(100.0)$ \\
\hline 9 & 414 & $3(27.3)$ & $8(72.7)$ & $2(66.7)$ & $1(33.3)$ \\
\hline 10 & 690 & $2(25.0)$ & $6(75.0)$ & $1(7.1)$ & $13(92.9)$ \\
\hline 11 & 369 & $3(30.0)$ & $7(70.0)$ & $1(33.3)$ & $2(66.7)$ \\
\hline$N$ & 8,567 & 58 (28.9) & 143 (71.1) & 27 (12.6) & $188(87.4)$ \\
\hline
\end{tabular}

As shown in Table 3, there are five variables for the staffing characteristics. The minimum and the maximum indicated the lowest and the highest values of each staffing variable in a maternity unit. Within a year, a unit with the lowest nurse to birth ratio indicated assigning one nurse to provide care for 21.5 births, while the highest nurse to birth ratio occured in a unit with 200.2 births for each nurse. The mean nurse to birth ratio was 69 , which can be explained by there being 69 births for every nurse per year, on average. Similarly, a maternity unit with the lowest midwife to birth ratio had 20.4 births for every midwife, while units with the highest midwife to birth ratio assigned one midwife for 159.0 births. The average midwifery staffing ratio was 67.5 births per year for every midwife.

Table 3. Descriptive statistics of staffing characteristics at the maternity unit level ( $N=11$ units)

\begin{tabular}{|c|c|c|c|c|}
\hline Staffing variables & Minimum & Maximum & Mean & SD \\
\hline Nurse to birth ratio (per year) & 21.5 & 200.2 & 69.0 & 61.991 \\
\hline Midwife to birth ratio (per year) & 20.4 & 159.0 & 67.5 & 47.914 \\
\hline Nursing experience (mean years) & 2.7 & 21.6 & 11.13 & 5.737 \\
\hline Midwifery experience (mean years) & 6.7 & 26.0 & 11.29 & 5.231 \\
\hline Proportion of bachelor's degree & 6.3 & 45.5 & 22.54 & 11.643 \\
\hline
\end{tabular}

To test the relationship between the variables of staffing characteristics and severe maternal outcome adjusted to the other variables (women and care provision), a multivariate logistic regression analysis was performed with the results shown in Table 4.

Our study has demonstrated that women admitted to units with a higher nurse to birth ratio were less likely to have a severe maternal outcome (OR $=0.476$; 95\% CI: 0.307-0.739) than women in units with a lower nurse to birth ratio. On the contrary, compared to maternity units with a lower midwife to birth ratio, units with a higher midwife to birth ratio had the likelihood of increasing the odds of women having a severe maternal outcome by 1.8 times (95\% CI: 1.070-3.059). Each increase of nursing experience by one year in maternity units would reduce the odds of severe maternal outcomes by $52 \%$ $(\mathrm{OR}=0.476 ; 95 \% \mathrm{CI}: 0.304-0.745)$. Every additional year of midwifery experience in maternity units also lowers the risk of severe maternal outcomes by $69 \%(\mathrm{OR}=0.313$; $95 \% \mathrm{CI}$ : $0.200-0.491)$.

Other non staffing variables on the provision of care also showed interesting results in relation to the severe maternal outcomes. Women admitted through a medical referral were more likely to experience a severe maternal outcome by 1.89 times than those without a medical referral (95\% CI: 1.2002.865). Women who delivered by caesarean section had increased odds of having a severe maternal outcome by approximately 53\% than their counterparts ( $\mathrm{OR}=1.528 ; 95 \% \mathrm{CI}$ : 1.106-2.112). Increasing the duration of the hospital stay by one day also increased the chance of having a severe maternal outcome by $19 \%(\mathrm{OR}=1.190 ; 95 \% \mathrm{CI}$ : 1.157-1.226).

\section{Discussion}

The prevalence of severe maternal outcomes (SMO) in this study was $2.6 \%(n=217)$, which is higher than the SMO prevalence reported by studies in Brazil (1.1\%) and the Netherlands (0.3\%) (de Jonge et al., 2015; Oliveira et al., 2014). Among women with SMOs, 15 women died after giving birth in the study hospitals, while the remaining 202 women experienced near misses. The estimated maternal mortality ratio in this study was 175 deaths per 100,000 live births. Although this figure seems lower than the national maternal mortality ratio, it is still considered as moderately high. It should be noted, 
Table 4. Multivariate logistic regression between explanatory variables and severe maternal outcomes

\begin{tabular}{|c|c|c|c|c|c|c|}
\hline Explanatory variables & B & SE & Wald & $P$-value & $\begin{array}{l}\text { Adjusted } \\
\text { OR }\end{array}$ & $\begin{array}{c}95 \% \text { CI } \\
\text { Lower-Upper }\end{array}$ \\
\hline \multicolumn{7}{|l|}{ Women's characteristics } \\
\hline Age & -0.008 & 0.011 & 0.557 & 0.455 & 0.991 & $0.971-1.013$ \\
\hline \multicolumn{7}{|l|}{ Place of residence } \\
\hline Outside city & & & & & 1.000 & \\
\hline Inside city & -0.092 & 0.163 & 0.317 & 0.574 & 0.912 & $0.662-1.256$ \\
\hline \multicolumn{7}{|l|}{ Type of complication } \\
\hline No complication or having other contributory conditions & & & & & 1.000 & \\
\hline Obstetric and other maternal complications & 0.276 & 0.149 & 3.432 & 0.064 & 1.318 & $0.984-1.765$ \\
\hline \multicolumn{7}{|l|}{ Provision of care } \\
\hline \multicolumn{7}{|l|}{ Admission procedure } \\
\hline No referral & & & & & 1.000 & \\
\hline Medical referral & 0.617 & 0.222 & 7.736 & $0.005^{\mathrm{b}}$ & 1.854 & $1.200-2.865$ \\
\hline \multicolumn{7}{|l|}{ Delivery method } \\
\hline Vaginal birth & & & & & 1.000 & \\
\hline Cesarean delivery & 0.424 & 0.165 & 6.599 & $0.010^{\mathrm{b}}$ & 1.528 & $1.106-2.112$ \\
\hline Length of stay & 0.175 & 0.015 & 138.338 & $0.000^{\mathrm{b}}$ & 1.190 & $1.157-1.226$ \\
\hline \multicolumn{7}{|l|}{ Staffing characteristics } \\
\hline Nurse to birth ratio & -0.742 & 0.224 & 10.969 & $0.001^{b}$ & 0.476 & $0.307-0.739$ \\
\hline Midwife to birth ratio & 0.593 & 0.268 & 4.889 & $0.027^{\mathrm{a}}$ & 1.809 & $1.070-3.059$ \\
\hline Nursing experience & -0.742 & 0.229 & 10.521 & $0.001^{b}$ & 0.476 & $0.304-0.745$ \\
\hline Midwifery experience & -1.162 & 0.229 & 25.649 & $0.000^{\mathrm{b}}$ & 0.313 & $0.200-0.491$ \\
\hline Bachelor's proportion & -0.284 & 0.265 & 1.146 & 0.284 & 0.753 & $0.448-1.26$ \\
\hline Constant & -4.0274 & 0.401 & 100.740 & $0.000^{\mathrm{b}}$ & 0.018 & \\
\hline
\end{tabular}

however, that the maternal deaths in the present study only included women who gave birth in hospital.

The estimated near-miss prevalence in the present study was $2 \%$, which is much smaller than the reported near-miss prevalence in a previous study at the district level of Indonesia. The near-miss prevalence rates in the district general and private hospitals were $17.2 \%$ and $4.2 \%$ respectively (Adisasmita et al., 2008). Another multi-country study of seven locations reported that the prevalence of potential near-miss events and actual near-miss cases were $15.0 \%$ and $4.0 \%$ of pregnancies respectively (Goldenberg et al., 2017). In our study, near miss cases included women who nearly died after surviving conditions of organ dysfunction such as shock, cardiac arrest, oliguria, and other life threatening conditions due to maternal related complications during pregnancy, childbirth or postpartum. It also includes other critical interventions received such as admission to an intensive care unit, hysterectomy, intubation and ventilation not related to anaesthesia, and massive blood transfusion. The different criteria applied to determine near miss cases might explain the various data on the near miss prevalence rates from different studies.

Our study showed that the average midwifery staffing ratio to birth was 1 midwife per 67.5 births in one year. Indonesia has not set up a minimum standard for the staff to birth ratio. Currently, the minimum requirement of maternity staffing in Indonesia hospitals is determined based on the hospital level and type (MoH, 2014). However, compared to the standard in some developed countries, this finding showed a much lower staffing ratio. The standardised staffing ratio in Australia is 1 full-time midwife per 30-40 births per year (QNMU, 2015), and 1 full-time midwife per 28 births in the United Kingdom (Sandall et al., 2014).

In this present study, the multivariate analysis revealed that all of the staffing characteristics, except the proportion of staff with a Bachelor's degree, were significantly associated with severe maternal outcomes in the selected tertiary hospitals after controlling the variables of age, place of residence, complications, admission procedure, mode of delivery, and the length of the patient's stay. These findings signify the importance of staffing in improving obstetric patient outcomes at the tertiary facility. Unexpectedly, the nurse to birth ratio and the midwife to birth ratio were both associated with severe maternal outcome - but in the opposite direction. Employing a higher nurse to birth ratio in maternity units would reduce the risk of severe maternal outcome. However, the chance of a woman suffering from a severe maternal outcome increased when they were admitted to units with a higher midwife to birth ratio. These findings justify the need to further understand to what extent midwives and nurses might have an interchangeable role in the maternity units. It could also be an indication of the hospital's interpretation of the Ministry of Health regulation that imposes the ratio of one patient per either nurse or midwife in the tertiary facilities $(\mathrm{MoH}, 2014)$.

One of the possible explanations for the decreasing probability of severe maternal outcomes in units with a higher nurse to birth ratio is that the nurses in maternity units might have received adequate training in maternal care. With more sufficient trained staff, the nurses would have more opportunity to provide a good standard of care to their patients (ICN, 2013). A previous randomised control trial found that, compared to women with usual care, women receiving one-to-one nurse labour support had a lower risk of oxytocin stimulation by $17 \%$ $(\mathrm{RR}=0.83 ; 95 \% \mathrm{CI}=0.67-1.04$ (Gagnon et al., 1997). This one-to-one care requires the nurse to be present throughout the labour and childbirth process to ensure that the birthing woman is physically comfortable and feels supported emotionally - as well as helping them with coping and relaxation strategies (Gagnon et al., 1997). A further study is recommended to investigate the contribution of training on obstetric care in reducing the risk of severe maternal outcomes. 
A previous study using the data of 144 hospitals in England reported that a higher midwifery staffing level was associated with an intact perineum (OR $=1.132 ; 95 \% \mathrm{CI}: 1.010-1.268)$ and childbirth without bodily damage $(\mathrm{OR}=1.110,95 \% \mathrm{CI}$ : 1.005-1.227) (Sandall et al., 2014). Another study also suggested that a higher midwife to birth ratio would lower the likelihood of hospital re-admission (95\% CI: -4.873 - -4.746) (Gerova et al., 2010). Contradictory to those findings, our study revealed an increased risk of severe maternal outcome in units with a higher midwife ratio. There is a possibility that the more severely ill patients were admitted to units with more midwives. Midwives are believed to have the proper knowledge and skills in obstetric care and are expected to assist the appropriate intervention in collaboration with other health professionals to improve the patient's outcome. However, having a higher number of midwives may not be of much help if the units care for patients with the most severe maternal complications. A previous study found that the level of severity was associated with severe maternal outcome (Roberts et al., 2009). As our data did not contain information on the acuity level, this assumption could not be confirmed.

In our study, units with more experienced nurses and midwives were less likely to have patients with severe maternal outcomes. This finding supports the evidence from the previous nursing studies that units with more highly experienced nurses lowered the odds of adverse patient outcomes (Blegen et al., 2001; Dunton et al., 2007). This finding adds a compelling rationale for the importance of health workforce retention at the health facility level in order to maintain a high quality of maternal care. This finding further highlights the significance of nursing and midwifery experience in improving maternal health outcome.

Provision of care as one of the crucial factors in maternal health service was also underscored in our study. The majority of patients were sent to the tertiary level by health providers working at the lower level. Previously, an Indonesian study also reported that almost two-thirds of obstetric patients in a tertiary hospital were referred from the lower levels of health care providers (Purnama et al., 2010). A severe maternal outcome is more likely to be experienced by patients who come to the hospital via a medical referral, with our study confirming the similar results of previous studies (Oliveira Neto et al., 2009; Yego et al., 2014). Inappropriate emergency management, a late referral to the upper-level facility, delays in making the diagnosis and the treatment procedure itself might contribute to this finding. A study by Mize et al. (2010) pointed out some of the issues in the Indonesia referral system which contributed to maternal deaths, including poor obstetric emergency care in the referred hospital, delays in making the referral decision, multiple referrals, inadequate compliance to the hospital standard operating procedures, the family's objection due to fearing the cost, and the absence of maternity staff.

In our study, more women had a caesarean delivery than any other mode of delivery. As this study was conducted at the tertiary level with the majority of women admitted through medical referrals, this finding was not surprising. However, the overall caesarean delivery rate of this study was $57.4 \%$, which is much higher than the caesarean delivery rate in tertiary hospitals in other developing countries such as Uganda (27.6\%) (Ugwu et al., 2011) and Pakistan (21.07\%) (Khawaja et al., 2004). A previous study comparing the caesarean rates at the tertiary level among ASEAN countries reported that Indonesia placed second (28.7\%) after Thailand (33.2\%), then followed by The Philippines (22.7\%) and Malaysia (19.1\%) (Festin et al., 2009). Interestingly, only Indonesia reported an indication of caesarean section based on maternal request at $3.7 \%$ of overall births at the tertiary level (Festin et al., 2009).

In the present study, women who underwent a caesarean delivery were 1.5 times more likely to experience a severe maternal outcome than those who had a vaginal birth $(95 \% \mathrm{CI}$ : 1.106-2.112). This finding confirms the previous study in the Latin America region, in that higher caesarean birth rates were associated with a greater risk of adverse maternal and neonatal outcomes (Villar et al., 2006). A woman's previous caesarean delivery, a lack of medical indication for caesarean delivery, and an elective caesarean section all increased the risk of a severe maternal outcome (Liu et al., 2007; Silver et al., 2006; Souza et al., 2010; Villar et al., 2006). Further investigation is needed to understand the hospital system, and other clinical as well as sociocultural factors that may relate to the high caesarean delivery rates among hospitals at different levels of care in Indonesia.

The third variable within the provision of care, the length of stay, showed a significant association with severe maternal outcomes. Every extra day in the hospital stay increased the probability of a severe maternal outcome by 1.19 times $(95 \%$ CI: 1.157-1.226), confirming the results of previous studies (Gerova et al., 2010; Özçelik et al., 2017). Liu et al. (2002) reported that the risk of re-admission increased among women who had undergone a caesarean delivery who were hospitalised for less than four days. For women who had gone through vaginal delivery, a longer hospital stay of more than four days was significantly associated with maternal re-admission (Liu et al., 2002). This finding implies that women might stay longer in the hospital due to a critical condition or complications, which require more complex treatment or intensive intervention.

Many studies consider that the various factors including the women's sociodemographic details and pregnancy-related conditions significantly affect the severe maternal outcomes (Oliveira Neto et al., 2009; Silver et al., 2006). Sandall et al. (2014) described the strong influence of maternal age, parity and clinical risk status in relation to the maternal outcome. However, three maternal variables that were analysed in this study, namely age, place of residence, and complications, were found to have no significant association with severe maternal outcome. Future research should consider adding in other maternal characteristics such as multiple pregnancies, antenatal check-up, the method of previous delivery, parity, and economic status to provide more adequate risk adjustment in the regression model.

\section{Limitations}

There were some limitations to our study. First, our study used secondary data from the electronic medical record system and personnel database system with a limited selection of variables available to analyse. The risk adjustment was not possible due to the limited number of variables. Second, a potential error may occur in determining the near-miss cases. Those cases were identified based on the diagnosis and interventions recorded in the electronic medical record without verification from the expert group. Third, the use of categorical variables in relation to the staffing characteristics may not represent the real staffing characteristics across the maternity units. However, the analysis of staffing characteristics in continuous variables failed the goodness fit test. The small number of units included in this study with a low variation of staffing levels might also interfere with the result. Fourth, the causal relationship could not be confirmed due to the cross-sectional nature of the study. 


\section{Conclusions}

Although we consider our results to be preliminary, the present study has further demonstrated the significance of healthcare workers in promoting maternal health outcomes, especially at the tertiary level of care. Maternity units that employ a higher ratio of nurses to births and have more experienced nurses and midwives reduce the risk of women having a severe maternal outcome (after adjustment to the factors related to the women's characteristics and the provision of care).

\section{Conflict of interests}

The authors declare that they have no conflict of interests.

\section{Acknowledgements}

This study was funded by the Ministry of Research, Technology and Higher Education of Indonesia through the "Penelitian Terapan Unggulan Perguruan Tinggi” scheme (Grant number 004/ADD/SP2H/LT/DRPM/VIII/2017).

\section{Kvalita zdravotnického personálu a vztah mezi ní a komplikacemi při porodu v indonéských terciárních nemocnicích}

\section{Souhrn}

Cíl: Zdravotnický personál je považován za jeden ze zásadních faktorů ve snaze snížit mortalitu a morbiditu při porodu. Náš výzkum si klade za cíl prozkoumat vztah mezi kvalitou zdravotnického personálu a komplikacemi při porodu.

Metodika: Byla provedena retrospektivní průřezová studie, ve které byla analyzována data týkající se porodů a zdravotnického personálu ve vysoce specializovaných (terciárních) nemocnicích $\mathrm{v}$ indonéském regionu Jáva.

Výsledky: Tato studie odhalila, že kvalita zdravotnického personálu je silně spojena s výskytem komplikací při porodu. Porodní sály s větším poměrem zdravotnického personálu na jeden porod omezily pravděpodobnost výskytu komplikací při porodu o $52 \%$ $(\mathrm{OR}=0.476 ; 95 \% \mathrm{CI}: 0.307-0.739)$. Na porodních sálech s větším poměrem porodních asistentek na jeden porod nicméně došlo k 1,8násobnému zvýšení pravděpodobnosti komplikací při porodu (OR = 1.809; 95\% CI: 1.070-3.059). Pravděpodobnost výskytu komplikací při porodu na porodních sálech je u zdravotních sester snížena o 52 \% za každý další odsloužený rok (OR = 0.476; 95\% CI: 0.304-0.745) a o 69 \% za každý další odsloužený rok u porodních asistentek (OR = 0.313; 95\% CI: 0.200-0.491).

Závěr: Zjištěné skutečnosti ukazují význam zdravotnického personálu v mateřské péči na terciární úrovni. Doporučuje se provést další výzkum, který by dále podpořil zavádění zdravotní politiky založené na faktech při nastavování standardů zdravotní péče pro zdravotnický personál v rámci mateřské péče.

Klíčová slova: Indonésie; maternal near-miss; terciární zdravotnictví; úmrtnost při porodu; zdravotnický personál

\section{References}

1. Adisasmita A, Deviany PE, Nandiaty F, Stanton C, Ronsmans C (2008). Obstetric near miss and deaths in public and private hospitals in Indonesia. BMC Pregnancy and Childbirth 8(1): 10. DOI: $10.1186 / 1471-2393-8-10$.

2. Aiken LH, Sloane DM, Bruyneel L, Van Den Heede K, Griffiths P, Busse R, et al. (2014). Nurse staffing and education and hospital mortality in nine European countries: a retrospective observational study. The Lancet 383(9931): 1824-1830. DOI: 10.1016/S0140-6736(13)62631-8.

3. ASEANstats (2015). ASEAN Statistical Year Book 2015. [online] [cit. 2018-10-19]. Available at: http://asean.org/ storage/2012/05/ASEAN-Statistic-Yearbook-2015_r.pdf

4. Balitbangkes-MoH, \& UNFPA. (2012). Disparitas, Akses dan Kualitas. Kajian Determinan Kematian Maternal di Lima Region Indonesia (Disparity, Access and Quality. A study on Maternal Death Determinants in Five Regions of Indonesia). In. Jakarta: Kemenkes RI and UN Population Fund.

5. Blegen MA, Vaughn TE, Goode CJ (2001). Nurse Experience and Education: Effect on Quality of Care. Journal of Nursing Administration, 31(1): 33-39. [online] [cit. 2018-10-

20]. Available at: https://journals.lww.com/jonajournal/ Fulltext/2001/01000/Nurse_Experience_and_Education_ Effect_on_Quality.7.aspx

6. de Jonge A, Mesman JA, Manniën J, Zwart JJ, Buitendijk SE, van Roosmalen J, van Dillen J (2015). Severe adverse maternal outcomes among women in midwife-led versus obstetrician-led care at the onset of labour in the Netherlands: a nationwide cohort study. PLoS One 10(5): e0126266. DOI: 10.1371/journal. pone. 0126266 .
7. Donabedian A (2002). An introduction to quality assurance in health care. USA: Oxford University Press.

8. Dunton N, Gajewski B, Klaus S, Pierson B (2007). The Relationship of Nursing Workforce Characteristics to Patient Outcomes. OJIN: The Online Journal of Issues in Nursing 12(3). DOI: 10.3912/OJIN.Vol12No03Man03.

9. Festin MR, Laopaiboon M, Pattanittum P, Ewens MR, Henderson-Smart DJ, Crowther CA, SEA-ORCHID Study Group (2009). Caesarean section in four South East Asian countries: reasons for, rates, associated care practices and health outcomes. BMC Pregnancy and Childbirth 9: 17. DOI: 10.1186/1471-2393-9-17.

10. Firoz T, Chou D, von Dadelszen P, Agrawal P, Vanderkruik R, Tuncalp O, et al. (2013). Measuring maternal health: focus on maternal morbidity. Bull World Health Organ 91(10): 794-796. DOI: 10.2471/BLT.13.117564.

11. Gagnon AJ, Waghorn K, Covell C (1997). A Randomized Trial of One-to-one Nurse Support of Women in labor. Birth 24(2): 71-77. DOI: 10.1111/j.1523-536X.1997.00071.pp.x.

12. Gerova V, Griffiths P, Jones S, Bick D (2010). The association between midwifery staffing and outcomes in maternity units in England: observational study using routinely collected data. [online] [cit. 2018-10-18]. Available at: http://www. kcl.ac.uk/nursing/research/nnru/publications/Reports/ NNRUMidwiferyReportDec10.pdf

13. Goldenberg RL, Saleem S, Ali S, Moore JL, Lokangako A, Tshefu A, et al. (2017). Maternal near miss in low-resource areas. Int J Gynaecol Obstet 138(3): 347-355. DOI: 10.1002/ijgo.12219.

14. ICN (2013). Safe staffing key to quality health care. [online] [cit. 2018-10-20]. Available at: http://www.icn.ch/images/stories/ documents/news/press_releases/2013_PR_13_Safe\%20staffing. pdf 
15. Joyce R, Webb R, Peacock JL (2004). Associations between perinatal interventions and hospital stillbirth rates and neonatal mortality. Arch Dis Child Fetal Neonatal Ed 89(1): F51-F56. DOI: 10.1136/fn.89.1.F51.

16. Khawaja N, Yousaf T, Tayyeb R (2004). Analysis of caesarean delivery at a tertiary care hospital in Pakistan. J Obstet Gynaecol 24(2): 139-141. DOI: 10.1080/01443610410001645415.

17. Kurniati A, Chen CM, Efendi F, Berliana SM (2018). Factors influencing Indonesian women's use of maternal health care services. Health Care Women Int 39(1): 3-18. DOI: 10.1080/07399332.2017.1393077.

18. Kurniati A, Rosskam E, Afzal MM, Suryowinoto TB, Mukti AG (2015). Strengthening Indonesia's health workforce through partnerships. Public Health 129(9): 1138-1149. DOI: 10.1016/j. puhe.2015.04.012.

19. Liu S, Heaman M, Kramer MS, Demissie K, Wen SW, Marcoux S (2002). Length of hospital stay, obstetric conditions at childbirth, and maternal readmission: A populationbased cohort study. American journal of obstetrics and gynecology 187(3): 681-687. DOI: https://doi.org/10.1067/ mob.2002.125765

20. Liu S, Liston RM, Joseph KS, Heaman M, Sauve R, Kramer MS (2007). Maternal mortality and severe morbidity associated with low-risk planned cesarean delivery versus planned vaginal delivery at term. CMAJ 176(4): 455-460. DOI: 10.1503/ cmaj.060870.

21. Makhfudli M, Efendi F, Kurniati A, Pradanie R, Sebayang SK (2019). What are the Staffing Levels and Maternal Outcomes? A Descriptive Study in Referral Hospitals in Java, Indonesia. Indian Journal of Public Health Research \& Development 10(7): 631-636.

22. Mize L, Pambudi E, Koblinsky M, Stout S, Marzoeki P, Harimurti P, Rokx C (2010).... and then she died: Indonesia maternal health assessment. [online] [cit. 2018-10-23]. Available at: https:// openknowledge.worldbank.org/bitstream/handle/ 10986/2837/533270ESW0Whit10Box345625B01PUBLIC1. pdf?sequence $=1$

23. $\mathrm{MoH}$ (2014). Peraturan Menteri Kesehatan Republik Indonesia Nomor 56 Tahun 2014 Tentang Klasifikasi dan Perizinan Rumah Sakit [Regulation of the Minister of Health of the Republic of Indonesia Number 56 Year 2014 Regarding the Classification and Licensing Hospital]. Jakarta: Kementerian Kesehatan.

24. $\mathrm{MoH}$ (2016). Profil Kesehatan Indonesia 2015 [Indonesia Health Profile Year 2015]. Jakarta: Kemenkes.

25. MoH, WHO, POGI, IBI (2013). Buku Saku Pelayanan Kesehatan Ibu Di Fasilitas Kesehatan Dasar Dan Rujukan [Handbook of Maternal Health Service in Primary and Referral Facilities]. Moegni EM, Ocviyanti D (Eds). Jakarta: Kemenkes RI.

26. Oliveira FC, Surita FG, Pinto e Silva JL, Cecatti JG, Parpinelli MA, Haddad SM, et al. (2014). Severe maternal morbidity and maternal near miss in the extremes of reproductive age: results from a national cross- sectional multicenter study. BMC Pregnancy and Childbirth 14(1): 77. DOI: 10.1186/1471-2393-14-77.

27. Oliveira Neto AF, Parpinelli MA, Cecatti JG, Souza JP, Sousa MH (2009). Factors associated with maternal death in women admitted to an intensive care unit with severe maternal morbidity. Int J Gynaecol Obstet 105(3): 252-256. DOI: 10.1016/j.ijgo.2009.01.025

28. Özçelik M, Turhan S, Bermede O, Yılmaz, AA, Ünal N, Bayar MK (2017). Outcomes of Antepartum and Postpartum Obstetric Admissions to the Intensive Care Unit of A Tertiary University
Hospital: An 8-Year Review. Turk J Anaesthesiol Reanim 45(5): 303-309. DOI: 10.5152/TJAR.2017.56323.

29. Purnama DI, Madjid OA, Iljanto S (2010). Evaluation of Obstetric Emergency Referral Cases at Dr. Cipto Mangunkusumo Hospital January - December 2008. Indonesian Journal of Obstetrics and Gynecology (Vol. 34. No. 4. October 2010): 164-169. [online] [cit. 2018-10-25]. Available at: http:// indonesia.digitaljournals.org/index.php/IJOG/article/view/230

30. QNMU (2015). Ratios Save Lives Phase 2: Extending the care guarantee. The Queensland Nurses and Midwives' Union (QNMU). [online] [cit. 2018-10-09]. Available at: https:// www.qnmu.org.au/DocumentsFolder/Ratios\%20website/ Phase\%202/Ratios\%20Save\%20Lives\%20Phase\%202\%20 1017\%20FINAL.pdf

31. Roberts CL, Ford JB, Algert CS, Bell JC, Simpson JM, Morris JM (2009). Trends in adverse maternal outcomes during childbirth: a population-based study of severe maternal morbidity. BMC Pregnancy Childbirth, 9: 7. DOI: 10.1186/1471-2393-9-7.

32. Sandall J, Homer C, Sadler E, Rudisill C, Bourgeault I, Bewley S, et al. (2011). Staffing in maternity units. Getting the right people in the right place at the right time. [online] [cit. 201810-24]. Available at: https://www.kingsfund.org.uk/sites/ default/files/staffing-maternity-units-kings-fund-march2011. pdf

33. Sandall J, Murrells T, Dodwell M, Gibson R, Bewley S, Coxon K, et al. (2014). The efficient use of the maternity workforce and the implications for safety and quality in maternity care: a population-based, cross-sectional study. [online] [cit. 2018-10-27]. Available at: https://www.ncbi.nlm.nih.gov/ pubmed/25642571

34. Silver RM, Landon MB, Rouse DJ, Leveno KJ, Spong CY, Thom EA, et al. (2006). Maternal morbidity associated with multiple repeat cesarean deliveries. Obstet Gynecol 107(6): 1226-1232. DOI: 10.1097/01.AOG.0000219750.79480.84.

35. Souza J, Gülmezoglu A, Lumbiganon P, Laopaiboon M, Carroli G, Fawole B, Ruyan P (2010). Caesarean section without medical indications is associated with an increased risk of adverse short-term maternal outcomes: the 2004-2008 WHO Global Survey on Maternal and Perinatal Health. BMC Med 8(1): 71. DOI: 10.1186/1741-7015-8-71.

36. Tunçalp Ö, Hindin M, Souza J, Chou D, Say L (2012). The prevalence of maternal near miss: a systematic review. BJOG 119(6): 653-661. DOI: 10.1111/j.1471-0528.2012.03294.x.

37. Ugwu EOV, Obioha KCE, Okezie OA, Ugwu AO (2011). A fiveyear survey of caesarean delivery at a Nigerian tertiary hospital. Annals of medical and health sciences research 1(1): 77-84.

38. Villar J, Valladares E, Wojdyla D, Zavaleta N, Carroli G, Velazco A, et al. (2006). Caesarean delivery rates and pregnancy outcomes: the 2005 WHO global survey on maternal and perinatal health in Latin America. Lancet 367(9525): 18191829. DOI: 10.1016/S0140-6736(06)68704-7.

39. WHO (2018). Maternal mortality. [online] [cit. 2018-10-21]. Available at: http://www.who.int/news-room/fact-sheets/ detail/maternal-mortality

40. World Health Organization, Department of Reproductive Health and Research. (2011). Evaluating the quality of care for severe pregnancy complications: the WHO near-miss approach for maternal health. [online] [cit. 2018-10-22]. Available at: https://www.who.int/reproductivehealth/publications/ monitoring/9789241502221/en/

41. Yego F, D’Este C, Byles J, Williams JS, Nyongesa P (2014). Risk factors for maternal mortality in a Tertiary Hospital in Kenya: a case control study. BMC Pregnancy Childbirth 14(1): 38. DOI: 10.1186/1471-2393-14-38. 